sætter social uorden andetsteds, hvis hæmning af fjendskabet forudsætter uhæmmet fjendskab andetsteds eller $\mathrm{i}$ andre registre, hvis endelig 'det fremmede' altid er uhåndterbart for mennesker - hvordan kan vi så håbe på tilblivelsen af en diskurs, der anerkender staternes voldelige randfigurer som rationelle politiske modstandere? Jeg havde gerne set, at Thorup mere indgående havde diskuteret forholdet mellem disse to underløbende spor i bogen, det brutale og det demokratiske.

Samtidig må det understreges, at det netop er denne underliggende teoretiske spænding, der gør bogen svær at lægge fra sig. Jeg kan på det varmeste anbefale, at man følger Thorup i hans jagt på statens diskursive og militære eksistensform, gennem piraternes og terroristernes rædselsvækkende figurer.

Christiane Mossin

\section{Mikrohistorisk klassiker}

Carlo Ginzburg: Osten og ormene. Kosmos ifolge en 1500-tals moller. Oversattelse og efterskrift v. Ole Jorn. Forlaget Klim 2006, 255 sider, $285 \mathrm{kr}$.

Den italienske historiker Carlo Ginzburgs bog om den norditalienske møller Menocchio fra 1500-tallets sidste del er nu udkommet på dansk. Bogen er et hovedværk indenfor den mikrohistoriske genre, som i 1976, hvor bogen første gang udkom, var en nyskabelse. Det nye lå for det før- ste $\mathrm{i}$ emnevalget, $\mathrm{i}$ fokuseringen gennem en hel bog på et menneske, der måske ikke var helt almindeligt, men som heller ikke kunne hævdes at have spillet nogen vigtig rolle $i$ historien. Menocchios verden havde ingen berøring med de traditionelle emner for historieskrivningen så som konger og krige. For det andet blev almindeligheden eller det trivielle accentueret gennem detailstudiet af denne mand og hans tanker. De mindste hændelser og henkastede bemærkninger blev af Ginzburg samlet op, sat sammen og brugt til rekonstruktion af et 1500-tals-menneskes hverdag og tankemåder. Ginzburgs bog blev i 1980 oversat til engelsk, og det gav ham et internationalt gennembrud som mikrohistoriens grundlægger. Det var en hæder, Ginzburg ikke var udelt begejstret for. Osten og ormene var ikke af sin forfatter tænkt som programmatisk mikrohistorisk, men blev snarere taget til indtægt herfor af andre historikere.

Det mikrohistoriske perspektiv er ikke desto mindre markant til stede, og det viser, hvordan Menocchio har malet sit korn i bjerglandsbyen samtidig med, at han har tumlet med sine kosmologiske tanker. Og rekonstruktionen af hans hverdag viser også, at han ikke holdt sine tanker for sig selv. Det sidste førte ham til sidst ufrivilligt ind $i$ en af tidens store konflikter, konfessionaliseringen og kampen om den rette tro. Derved bliver Menocchios lille historie også et spejl af "de store begivenheder" på det makrohistoriske plan. 
Ginzburg kunne skrive sin bog, fordi inkvisitionen efterhånden begyndte at interessere sig for Menocchio, og gennem lange afhøringer af ham møjsommeligt noterede hans svar på forhørsledernes spørgsmål ned. Helt almindelig var Menocchio ikke; han var en skæv person, en bonde med selvstændige og uautoriserede tanker om kosmos. Mange mikrohistoriske studier leder efter resterne af hverdagens levede liv: det liv, der var det mest almindelige, men som også har efterladt sig færrest spor. Sporene, Menocchio efterlod sig, skyldes netop hans særpræg, og de kunne derfor blive opdaget af Ginzburg i inkvisitionens arkiver. Men netop gennem disse forhørsprotokoller, som tydeligt afspejler forhørsledernes måben over møllerens tankegang, får vi et billede frem af en modkultur, en for længst forsvundet og besejret mentalitet. Det bekræfter, at sejrherrerne, i dette tilfælde den katolske kirke, skriver historien. Folk som Menocchios tanker kan kun genfindes ved hiælp af detektivarbejder som Ginzburgs.

Bogens titel refererer til Menocchios opfattelse af verdens skabelse som selvbefrugtning: verden var som en ost, hvoraf livet myldrede frem som orme. Spørgsmålet er, om det var en gal mands tanker, eller om der lå en mere alment udbredt kulturel ballast bag? Ginzburg sandsynliggør overbevisende, at Menocchio tilhørte en understrøm af bondematerialisme, som havde suget næring af den lærde verden, og havde tilknytning til pro- testantiske strømninger - eller som i det mindste så med stor skepsis på kirkens vidensmonopol. Karakteristisk for Menocchio var, at han i lighed med mange folkereligiøse strømninger (både dengang og nu), havde et udogmatisk og synkretistisk forhold til mange trossætninger. Han erklærede over for inkvisitionsdommerne, at han ikke med sikkerhed vidste, hvem der havde mest ret i deres tro, de kristne, jøderne eller tyrkerne, for de var jo alle Guds børn. Men når han nu var født kristen, og hans forfædre også havde været kristne, ville han også blive ved med at være det, beroligede han sine dommere med. Som man kan tænke sig, følte dommerne sig ikke meget betryggede derved, og Menocchio blev idømt fængsel for sine kætterier. Efter nogle år blev han benådet, idet man gjorde sig forhåbninger om, at han var kommet på bedre tanker, dvs. havde taget den katolske kirkes dogmer til sig. Han faldt dog snart tilbage i sin gamle åbenmundede, kætterske gænge og blev som relapsus omkring 1600 henrettet. Det skete, som Ginzburg slutter sin bog med at sige, $\mathrm{i}$ et bevidst forsøg på at undertrykke og udslette den folkelige kultur, som Menocchio var en del af.

Ginzburgs forsøg på at kaste lys over denne udslettede kultur består dels af analyser af Menocchios egne forklaringer, dels gennem sammenligninger med mulige litterære forlæg, fx Boccaccio og Mandevilles rejser, som viser, hvad Menocchio har læst, eller 
måske snarere forlæst sig på, for det meste har han misforstået eller frit genfortolket ind i sin egen verden af bondefornuft. På den måde er Ginzburgs bog også en lærerig studie i receptionshistorien: man kan ikke bare slutte sig til, at fordi så og så mange har læst en eller anden forfatter, så er denne forfatters tanker blevet udbredt til læserne. Læseren er et filter, en transformator, måske ligefrem en forvansker. Som Ginzburg selv formulerer det: "Det var ikke selve bogen, men mødet mellem de skrevne sider og den mundtlige kultur, der dannede en sprængfarlig blanding $i$ Menocchios hoved".

Kulturmødet har også betydning for den måde, vi kan lære Menocchio at kende. Også ham kender vi kun gennem et filter, nemlig inkvisitionen, hans dommere og skriveren. Den sidste er særlig vigtig, for det var ham, der skulle notere og sikkert også i gentagne tilfælde ordne og sammenfatte Menocchios ord under forhørene. Og hvilke forudsætninger havde han for det? Menocchios sag viser, at trosforestillinger ikke kun kan anskues som sivende ned fra de højere samfundslag til de lavere. Der fandtes en $i$ vid udstrækning mundtlig folkekultur, som er meget svær at rekonstruere pga. af manglen på skriftlige hjælpemidler. Det sker derfor også at Ginzburg gætter på, hvad Menocchio kunne have læst. Her er Ginzburg ikke altid lige overbevisende, men dristighed er hans adelsmærke og han gør da også behørigt opmærksom på, at disse dele af hans analyse er mindre velunderbyggede.

Ginzburg står naturligvis overfor et metodisk problem, når han skal sætte den mundtlige bondekultur ind i en historisk kontekst, for det må ske vha. af nedfældede kilder, hvad enten det er forhørsprotokoller, manuskripter eller trykte bøger. Ofte er det nærmeste Ginzburg kan komme det, at Menocchios tanker minder om noget andet, og hans tese, at Menocchios tanker repræsenterer en fjern og dunkel møllerkultur i videre forstand, bliver derfor selv noget dunkle. Det rokker dog ikke ved, at bogen er uvurderlig som en dør ind til en snurrig, men tabt folkekultur, filosofisk vidtløftig og snusfornuftig på samme tid.

Udgaven består af 200 siders tekst og 50 siders noter. Særligt hvad angår Ginzburgs forord, hvor disse noter henviser til 1970'ernes forskningsdebatter, mærkes bogens alder, men, som oversætteren gør rede for i sit udmærkede efterskrift, er attraktionen ved Ginzburgs bog ikke bare den i sig selv medrivende fortælling om Menocchios skæbne, men også forskningsmetoden og den litterære præsentation er stadig aktuel. $\mathrm{Og}$ på den baggrund er det naturligt, at noteapparatet er bibeholdt, nærmest som et monument over Ginzburgs metode og stil.

Morten Fink-Jensen 